\title{
A new report on mycobiota associated with Ropalidia marginata paper nests
}

\author{
A. Jayaprakash and P. Ebenezer \\ Centre for Advanced Studies in Botany, University of Madras, Guindy Campus, Chennai- 600 025, Tamil Nadu, India \\ aruljaypee@gmail.com
}

\begin{abstract}
Twenty four fungal species were isolated from the paper nests of common Indian paper wasp Ropalidia marginata. The genus Aspergillus was dominant while Penicillium recorded next in the paper nests. Among Aspergillus spp., $A$. niger was most abundant (14\%), followed by $A$. flavus (7\%). Among Penicillium spp., $P$. citrinum occurred high $(9 \%)$ followed by $P$. oxalicum $(2 \%)$. The nest material analysed by GC-MS revealed that it was predominantly wax and that the components were mainly hydrocarbons.
\end{abstract}

Keywords. Mycoflora, Aspergillus, Paper nests, Penicillium, Ropalidia marginata, wasp, new report.

Introduction

Insects, like many eukaryotes could be strongly influenced by the microbes they harbour. Microbial associates of insects are implicated in the degradation of plant materials, synthesis of vitamins and in relatively rare cases, induction of disease etc. (Dillon \& Dillon, 2004). Social insects provide unique resources for microbial symbionts, due to high density of individuals within colonies, sharing of food and other resources and the coexistence of colony members from multiple generations. Not surprisingly then, symbioses between social insect species and microbial species are common and often they coevolved. Many species of termites and ants for instance, are obligately tied to specific microbes for their nutritional needs (Sauer et al., 2000; Dolan, 2001; Moran et al., 2003).

Ropalidia marginata (Lep.) (Hymenoptera: Vespidae), widely distributed in Peninsular India has been considered a primitively eusocial species because of the absence of morphological differentiation between queens and workers and because many, if not all, female wasps can mate, develop their ovaries and function as solitary nest foundresses or as queens of multiple foundress nests. The social wasp genus, Ropalidia has long been considered crucial to understanding the evolution of hymenopteran sociality because it contains both independent-founding, primitively eusocial species that build small open nests and exhibit no morphological caste differentiation and swarm-founding, highly eusocial species that often build large, enveloped nests and may exhibit considerable queen-worker dimorphism (Sumana \& Gadagkar, 2003). R. marginata use paper (wood pulp) to build their nests. There are relatively few records of fungi infecting wasps themselves, a number of fungi having been reported from the nest material (any material within a nest, including nest paper, bits of dead wasps and old food scraps etc.). More often, these fungi thrive as saprotrophs and might be associated with the nest material or infect the dead wasps. But to date, information as to the fungi associated with $R$. marginata paper nests remains inaccessible. The study is aimed at the isolation of fungi associated with $R$. marginata paper nests.

\section{Material and Methods}

\section{Collection sites}

The paper nests of Ropalidia marginata were collected from six different sites in and around Chennai, Tamil Nadu, India. The sites are Arignar Anna Zoological Park, Vandalur; Botany field research laboratory, University of Madras, Maduravoyal, Indian Institute of Technology Campus, Adyar; Loyola College Campus, Nungambakkam; Madras Christian College Campus, Tambaram and University of Madras, Guindy Campus.

\section{Isolation of fungi from the paper nests of R.marginata}

Paper nests of $R$. marginata were surface sterilized with $0.1 \%$ mercuric chloride for $2 \mathrm{~min}$. and washed thoroughly in sterile distilled water for $2 \mathrm{~min}$ and the fragments plated on PDA and incubated at $25^{\circ} \mathrm{C}$ for a week. After isolation, the fungi were subcultured and the pure cultures were stored in PDA at $4^{\circ} \mathrm{C}$. All fungi were identified as per the Standard Mycology Manuals by Onions (1981) and Sutton (1980).

\section{Presentation of data}

The fungi isolated from the nests from the six collection sites were enumerated. The percentage contribution of the individual species was arrived at by applying the following formula:

$$
\begin{gathered}
\text { No. of CFU of an individual species } \\
\begin{array}{c}
\text { Total No. of CFU of all species } \\
\text { CFU }=\text { Colony forming units }
\end{array}
\end{gathered}
$$

Research communication

CIndian Society for Education and Environment (iSee)
"Mycobiont of paper nests" http://www.indjst.org
Jayaprakash \& Ebenezer Indian J.Sci.Technol. 


\section{Analysis of $R$. marginata nest material}

Fragments of $R$. marginata paper nest $(5 \mathrm{mg})$ were extracted in $25 \mathrm{ml}$ hexane and the extractant analysed in mass spectrum on a SHIMADZU GC-2010 model instrument using a phase $A: B(50: 50)$. Here $A$ is water and $B$ is acetonitrile solvent. Flow rate as $0.35 \mathrm{ml} / \mathrm{min}$., was used in this experiment.

\section{Results and discussion}

The paper nests of $R$. marginata were collected from six different sites in and around Chennai, Tamil Nadu, India (Fig. 1). The paper nests were confirmed as those of $R$. marginata by the Entomology Research Institute, Loyola College, Chennai, Tamil Nadu, India, based upon their morphological characteristics.

Fig. 1. Paper nest of Ropalidia marginata

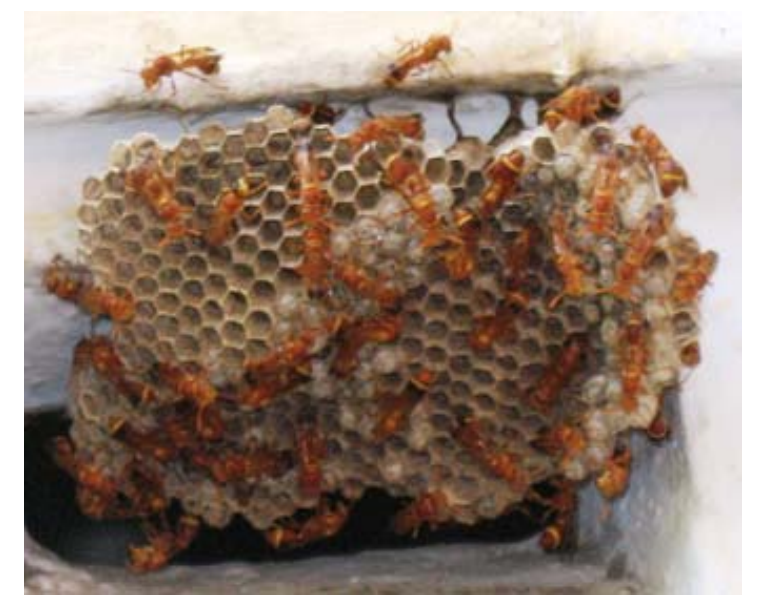

\section{Mycobiota inhabiting paper nests of $R$. marginata}

$R$. marginata, like many other eukaryotes are associated with microbes in their nests. Fungi associated with wasp nests have been implicated in the degradation of plant materials and other foods, synthesis of vitamins and in relatively rare cases, incitation of disease. Fungi associated with the paper nests of $R$. marginata have not been attempted previously and therefore, this investigation assumes significance. Many social wasps use plant fibres and other plant materials for building their nests of fascinating architectural patterns. The fungal hyphae are found interwoven with the fibres that make up the nests. The interwoven fungal hyphae may serve to strengthen the paper they make and hold it together (Durrell, 1965).

Twenty four fungal species in all, belonging to 3 Sub-divisions namely, Zygomycotina, Ascomycotina and Deuteromycotina were isolated from the paper nests of $R$. marginata. Aspergilli was the most prevalent amounting to $47.63 \%$ of the total fungal isolates realized. Of the Aspergillus spp., $A$. niger was most abundant with $14 \%$, followed by $A$. flavus with $7 \%$ and $A$. japonicus with $6 \%$. The predominance of the Aspergilli in this habitat is in consonance with the concept of ecological amplitude
Vol. 3 No. 1 (Jan 2010)

ISSN: 0974- 6846
(McIntosh, 1985). Next follows Penicillium with $13.18 \%$. Mucor racemosus, Rhizopus stolonifer, Chaetomium spirale, Curvularia lunata, Drechslera hawaiiensis and Fusarium oxysporum occurred as the least abundant organisms, each accounting for $2-6 \%$ of the total isolates (Table 1). There were also certain yeasts and some nonsporulating fungi that inhabited the paper nests. The occurrence of these fungi pointed to a possible chance association with the nest material. The association between fungi and wasp nest has been studied by several investigators (Durrell, 1965; Gilliam et al., 1974; Costa \& Oliveira, 1998; Madeira 1998). A wide variety of microorganisms have been isolated from nest material (Vespula, Vespa and Dolichovespula) (Rose et al., 1999).

\section{GC-MS analysis of $R$. marginata nest material}

The components present in $R$. marginata paper nest were extracted in hexane and analysed by GC-MS. Around 23 distinct peaks were observed. All the components were identified as hydrocarbons based on their fragmentation obtained form mass spectrum. The major hydrocarbon present in the nest was isolated at retention time of $27 \mathrm{~min}$. which matches that of n-heptocosane $\left(\mathrm{C}_{27} \mathrm{H}_{56}\right)$. The diagnostic peaks are 57.1, 71.1, 85.0, 97.1, 111.1, 207.1, 281.0 etc. (Fig. 2).

The nest material analysed by GC-MS revealed that it

Fia. 2.GC-MS analvsis of R. marainata paper nest

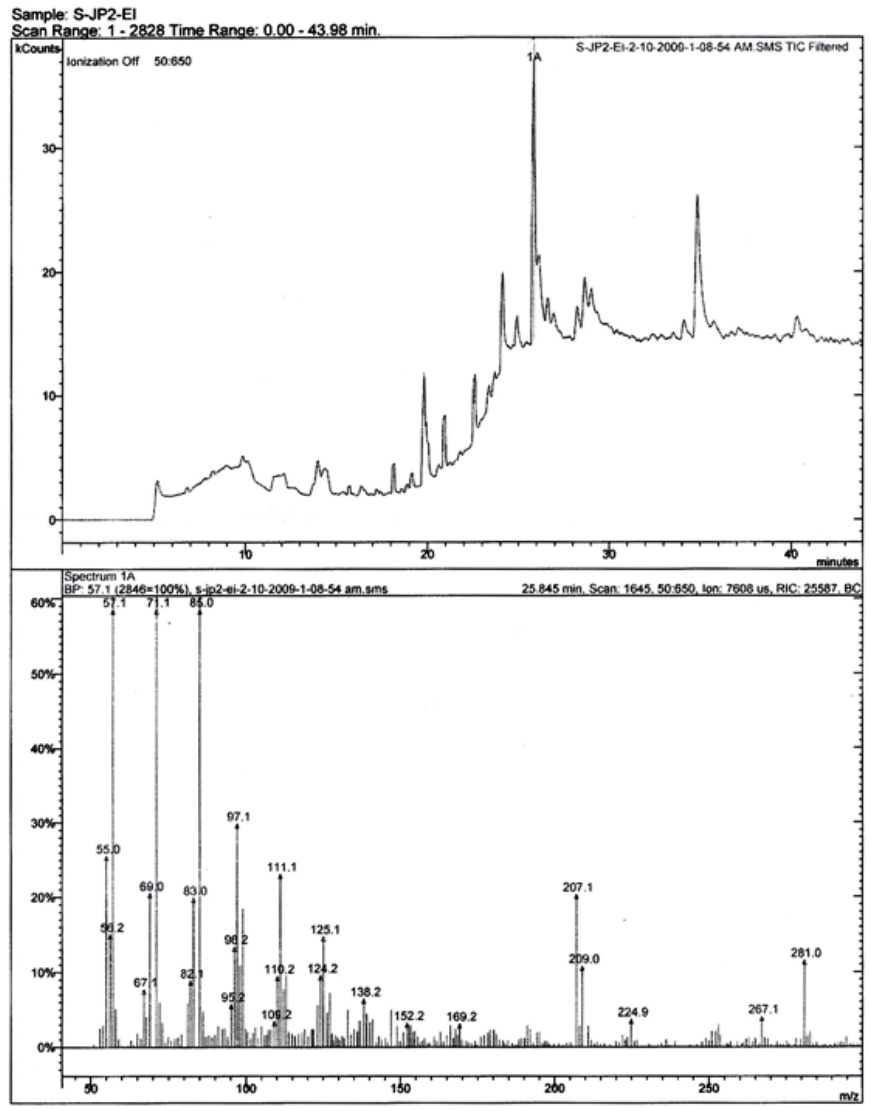

Research communication

(C)Indian Society for Education and Environment (iSee)
"Mycobiont of paper nests" http://www.indjst.org
Jayaprakash \& Ebenezer Indian J.Sci.Technol. 
was predominantly wax and that the components were mainly hydrocarbons-the major hydrocarbon being n-heptocosane $\left(\mathrm{C}_{27} \mathrm{H}_{56}\right)$ (Fig. 2). In Vespa analis nest, $85 \%$ of the nest material is made of wax according to Kameda et al. (2007) who also stated that the major hydrocarbon is n-heptocosane $\left(\mathrm{C}_{27} \mathrm{H}_{56}\right)$.

In conclusion, this investigation provides insight on the fungal biodiversity of the paper nests of wasp sp., $R$. marginata. This is also the first report on fungi associated with the common Indian paper wasp. Further investigation may lead to complete documentation of the fungal diversity of these paper nests.

Table 1. Fungi isolated from the paper nests of $R$. marginata

\begin{tabular}{|l|c|c|c|c|c|c|c|c|}
\hline \multicolumn{1}{|c|}{ Species } & $\begin{array}{c}\mathrm{AZ} \\
\mathrm{P}\end{array}$ & $\begin{array}{c}\mathrm{BF} \\
\mathrm{RL}\end{array}$ & $\begin{array}{c}\mathrm{CA} \\
\mathrm{SB}\end{array}$ & $\mathrm{IIT}$ & $\mathrm{LC}$ & $\begin{array}{c}\mathrm{MC} \\
\mathrm{C}\end{array}$ & $\begin{array}{c}\text { \# } \\
\text { CFU }\end{array}$ & $\begin{array}{c}\text { \% Contri } \\
\text {-bution }\end{array}$ \\
\hline ZYGOMYCOTINA & & & & & & & & \\
\hline Mucor recemosus & 18 & 14 & 12 & 8 & 15 & 10 & 77 & 5.35 \\
\hline Rhizopus stolonifer & 10 & 8 & 10 & 14 & 7 & 12 & 61 & 4.23 \\
\hline ASCOMYCOTINA & & & & & & & & \\
\hline Chaetomium spirale & 8 & 6 & - & 3 & 6 & 2 & 25 & 1.73 \\
\hline DEUTEROMYCOTINA & & & & & & & & \\
\hline Alternaria alternata & 13 & 10 & 12 & 9 & 16 & 10 & 70 & 4.86 \\
\hline $\begin{array}{l}\text { Aureobasidium } \\
\text { pullulans }\end{array}$ & 6 & - & 4 & 6 & 10 & 8 & 34 & 2.36 \\
\hline Aspergillus flavus & 10 & 12 & 18 & 24 & 20 & 16 & 100 & 6.94 \\
\hline A. fumigatus & 18 & 12 & 13 & 16 & 9 & 10 & 78 & 5.42 \\
\hline A. japonicus & 14 & 10 & 14 & 22 & 18 & 9 & 87 & 6.04 \\
\hline A. nidulans & 10 & 9 & 12 & 14 & 10 & 8 & 63 & 4.37 \\
\hline A. niger & 25 & 27 & 28 & 45 & 36 & 40 & 201 & 13.96 \\
\hline A. terreus & 12 & 16 & 24 & 19 & 14 & 8 & 93 & 6.46 \\
\hline A. ochraceus & 8 & 10 & 14 & 10 & 10 & 12 & 64 & 4.44 \\
\hline Curvularia lunata & 6 & 4 & 4 & 6 & - & 2 & 22 & 1.52 \\
\hline C. ovoideae & 4 & 2 & 4 & 8 & 4 & 6 & 28 & 1.94 \\
\hline $\begin{array}{l}\text { Cladosporium } \\
\text { cladosporioides }\end{array}$ & - & 9 & 11 & 10 & 7 & 6 & 43 & 2.98 \\
\hline Drechslera hawaiiensis & 8 & 4 & 7 & 3 & 5 & - & 27 & 1.87 \\
\hline Fusarium oxysporum & 2 & 3 & 1 & 5 & - & 3 & 14 & 0.97 \\
\hline Paecilomyces variotii & - & 11 & 10 & 8 & 6 & 7 & 42 & 2.91 \\
\hline Penicillium citrinum & 22 & - & 24 & 36 & 30 & 18 & 130 & 9.03 \\
\hline P. frequentans & - & 7 & 2 & 6 & - & 5 & 20 & 1.38 \\
\hline P. oxalicum & 2 & 10 & 5 & 8 & - & 3 & 28 & 1.94 \\
\hline P. variabile & - & 4 & 2 & 4 & - & 2 & 12 & 0.83 \\
\hline Trichoderma viride & 8 & 10 & 10 & 14 & 8 & - & 50 & 3.47 \\
\hline Phoma sp. & 2 & 1 & - & 2 & 1 & - & 6 & 0.41 \\
\hline Yeast colonies & - & 4 & 7 & 5 & 4 & 8 & 28 & 1.94 \\
\hline Non-sporulating fungi & 6 & 4 & - & - & 8 & - & 36 & 2.50 \\
\hline AAZParignar Anna & $700 / 0 g i c a l ~$ & & & & & & \\
\hline
\end{tabular}

$A A Z P=$ Arignar Anna Zoological Park; IIT=Indian Institute of Technology

$B F R L=$ Botany Field Research Laboratory; MCC= Madras Christian College $C A S B=$ Centre for Advanced Studies in Botany; $L C=$ Loyola College
Vol. 3 No. 1 (Jan 2010)

ISSN: 0974- 6846
2. Dolan MF (2001) Speciation of termite gut protists: the role of bacterial symbionts. Int. Microbiol. 4, 203-208.

3. Durrell LW (1965) Fungi in nests of paper wasps. The American Midland Naturalist 73, 501-503.

4. Moran NA, Plague GR, Wilcox JL and Sandstrom JP (2003) A genomic perspective on nutrient provisioning by bacterial symbionts of insects. Proceedings of the National Academy of Science of United States of America 100, 14543-14548.

5. Onions AHS, Allsopp D and Eggins HOW (1981) Smith's introduction to industrial mycology. Edward Arnold, London.

6. Sumana A and Gadagkar R (2003) Ropalidia marginata a primitively eusocial wasp society headed by behaviourally non-dominant queens. Curr. Sci. 84(11),1464-1468.

7. Sutton BC (1980) Coelomycetes. CMI, Kew, Surrey, England.

8. Kameda $\mathrm{T}$, Akino $\mathrm{T}$ and Kojima $\mathrm{K}$ (2007) Wax components of larval cocoon silk of the hornet Vespa analis Fabricius. Analytical Bioanalytical Chem. 387, 2895-2902.

9. Carlile MJ and Watkinson SC (1996) The Fungi. Academic press, Harcourt Brace \& Co. Publishers. London.

10. Lockington R, Rodbourn L, Barnett S, Carter C and Kelly J (2002) Regulation by carbon and nitrogen sources of a family of cellulases in Aspergillus nidulans. Fungal Gene. Biol. 37,190196.

11.Fu X, Zhu X, Gao K and Duan J (1995) Oil and fat hydrolysis with lipase from Aspergillus sp. J. American Oil Chem. Soc. 72, 527-531.

12. Mclntosh RP (1985) The background of ecology concept and theory. Cambridge University Press.

13. Gilliam M, Prest DB and Morton HL (1974) Fungi isolated from Honey Bees, Apis mellifera, Fed 2, 4-D and antibiotics. J. Invertebrate Pathol. 24, 213-217.

14. Costa GL and Oliveira PC (1998) Penicillium species in mosquitoes from two Brazilian regions. J. Basic Microbiol. 38, 343-347.
Acknowledgement

The authors thank Prof. R. Rengasamy, Director, C.A.S. in Botany, University of Madras for providing necessary laboratory facilities.

References

1. Dillon RJ and Dillon VM (2004) The gut bacteria of insects: nonpathogenic interactions. Ann. Rev.

15. Madeira NG (1998) Persistence of conidia of Entomophthora muscae in relation to age, temperature and humidity. Biocontrol. 43, 87-95.

16. Rose EAF, Harris RJ and Glare TR (1999) Possible pathogens of social wasps (Hymenoptera: Vespidae) and their potential as biological control agents. Nzl. J. Zoo. 26,179-190.

Entomol. 49, 71-92.

Research communication

(C)Indian Society for Education and Environment (iSee)
"Mycobiont of paper nests" http://www.indjst.org
Jayaprakash \& Ebenezer Indian J.Sci.Technol. 